ORIGINAL ARTICLE

\title{
Higher Body Mass Index and Waist Cicumference Have Correlation With the degree of Curvature of Hyperlordosis in Young Adult
}

\author{
Fitriani Rahmawati, Nuryani Sidarta \\ Faculty of Medicine, University of Trisakti, Jakarta, Indonesia
}

\begin{abstract}
BACKGROUND : Health problem that caused by higher BMI have grown broadly. Musculoskeletal disorders due to higher BMI will cause an excessive burden on the lumbosacral joints. .Moreover, excess waist circumference can also lead to malformation of lumbal curvature.
\end{abstract}

Purpose: This study aims to determine the relationship between higher Body Mass Index (BMI) and excess waist circumference with the higher curvature in young adult.

Method: This study used observational study with cross-sectional design involving 88 students who performed measurement of body weight, height, and waist circumfrences, also lumbar curve examination. The measurement of waist circumference was done by circling the flexible tape on waist. For the measurement of the lumbar curve,each respondent is measured by a flexible ruler.

Results: chi square test obtained $p=0,000$ in high BMI with the increasing of lumbar curve and $p=0,000$ in excess waist circumference with the increasing of lumbar curve. So, there is a correlation between higher BMI and excess waist circumference with the increase of lumbar curve in the young adults.

Conclusions: In this study showed that higher BMI and excess waist circumference have correlation with the increase of lumbar curve in the students.

Keywords: body mass index, waist circumference, tape measure, hyperlordosis, flexible ruler.

\section{Correspondent Detail:}

Fitriani Rahmawati

Email: fitrianirahmawati02@gmail.com

Faculty of Medicine, University of Trisakti Kampus B

Jl. Kyai Tapa, Grogol, , Jakarta Barat 11440 


\section{INTRODUCTION}

Higher Body Mass Index (BMI) is recognized as a major public health problem. Basic Health Research Indonesia (Riskesdas) in 2013, showed the prevalence of obesity in adult age group was $15.4 \%$ and overweight by $13.5 \%$, then the prevalence of the Indonesian population with the higher BMI were $28.9 \%$. In Indonesia and other developing countries, health issues related to obesity has grown widely, while the first this problem is more prevalent in advanced countries. ${ }^{1} \mathrm{BMI}$ is categorized as underweight $\left(16-18.5 \mathrm{~kg} / \mathrm{m}^{2}\right)$, normal $\left(18.5-25 \mathrm{~kg} / \mathrm{m}^{2}\right)$, overweight $\left(25-30 \mathrm{~kg} / \mathrm{m}^{2}\right)$, and obesse $(>30 \mathrm{~kg} /$ $\mathrm{m}^{2}$ ). In this study, higher BMI included overweight and obesse.

Obesity will have an impact on various health complications such as cardiovascular disorder, neurovascular disorder, also associated with various muskuloskeletal disorder, including impairment of the spine. According to Parjoto, higher rate of BMI can increase the load of the lumbosacral joints, so it will causes the malformation of the lumbar's curve (hyperlordosis). The prevalence of musculoskeletal disorder reached $40 \%$. In Indonesia estimated prevalence rate $37 \%$.

According to Soontharee, the Body Mass Index will affect the lumbar angle. This research was comparing the angle between the upper and lower lumbar angle on adults who have a normal body mass index (BMI) and excess body weight, also excess waist circumference. The re- sult from this study showed there is a significant relationship between Body Mass Index with an increase of lower lumbar angle, however excess waist circumference shows no association with the increase of lumbar angle (hyperlordosis).

According to the previous studies, lumbar's angle is significantly larger on individuals with higher Body Mass Index (BMI). The occurrence of hyperlordosis in individuals with higher rate of BMI is due to compensation to improve balance. ${ }^{6}$

The gold standard for examine hyperlordosis is using X-ray. X-rays are useful to detect body's deformity. Level radiation exposure is considered safe for mostly adults. But it is not recommended in children because it can causes the dangers of radiation. Tizabi et al developing a safe diagnostic tool used to measure hyperlordosis. It is called flexible ruler, which is faster, cheaper, and more simple.

Flexible ruler is a ruler covered with plastic depicted in 40,50, and $60 \mathrm{~cm}$ can be bent in one area and can retaining the shape of the bend. So this tool can be used for measure the increase in lumbar lordosis and thoracic kyphosis with high enough validity $(\mathrm{ICC}=0.97) .{ }^{8,9}$ Based on the above explanation, researchers' want to research further about the relationship of higher BMI and waist circumfrence with the increased lumbar curve (hyperlordosis) by using flexible ruler measurement method. 


\section{METHOD}

This research was conducted in the students of Faculty of Civil Engineering batch 2015, University of Indonesia, Depok, started from August to September 2017. This research used observational analytics with cross-sectional approach. The variables were measured at the same time. The goal is to know the relationship between higher BMI and waist circumfrence with the increase of lumbar curve (hyperlordosis) in students. Respondents will measured for the body weight, height, waist circumfrence, then examined lumbal's curve.

In this study, the sampling technique used consecutive non-random sampling according to the size of the sample that is calculated and according to the inclusion criteria and exclusion criteria in this study. The inclusion criteria in this study were both male and female students, who understood and followed the instruction, healthy, and willing to be researched. The exclusion in this study was the presence of pregnant, weight lifter, marathon running athlete, rugby athletes, soccer athletes, having spondilolisthesis, low back pain, spinal degenerative disorders, and abnormalities of bone structure.

In this study data collection obtained through primary data collection from questionnaires and measurement. Questionnaire that be used including sociodemography. The measurement of BMI was done by measure the body weight and height. The measurement of waist circumfrence was done by take a regular breath, so the stom- ach is in a normal state, then circling the tape measure loosely from the midpoint between arcus costae and suprailiaca around the stomach. ${ }^{10}$ For the measurement of the lumbar curve, respondents were positioned standing in a relaxed position without use any footwear. The lumbar curve of each respondent is measured by a flexible ruler and the results draw into plain white paper.

\section{RESULTS}

In this study the number of respondents who included are 88 people with the number of female was $30(34,1 \%)$ and men was $58(65,9 \%)$. The range of age was 20-24 years.

\section{Table 1. Respondent Characteristic}

\begin{tabular}{lcc}
\multicolumn{1}{c}{ Variable } & N & $\%$ \\
\hline Body Mass Index & 37 & 42,0 \\
Normal & 27 & 30,7 \\
Overweight & 24 & 27,3 \\
Obesse & & \\
Waist Cirreunfrence & 59 & 67,0 \\
Normal & 29 & 33,0 \\
Excess & & \\
Lumbal Curve & 51 & 58,0 \\
Normal & 37 & 42,0 \\
Hyperlordosis & & \\
\hline
\end{tabular}

From table 1, it can be seen that more than half of respondents do not have normal body mass index. 24 from 88 respondents or 27.3 percent respondents have higher BMI. For the high- 
er curvature in hyperlordosis from 88 respondents, there were 37 respondents or 42.0 percent. However, in the waist circumfrence was find 29 respondents or 33.0 percent in excess waist circumference.
Chi-Square Analysis Researcher used bivariat data analized with chi-square using SPSS (Statistical Package for the Social Sciences) and obtained the following results:

Table 3. The Relationship between High Body Mass Index (BMI) with Hyperlordosis

\begin{tabular}{|c|c|c|c|c|}
\hline \multirow{2}{*}{$\begin{array}{c}\text { Body Mass } \\
\text { Index }\end{array}$} & \multicolumn{2}{|c|}{ Lumbal Curve } & \multirow{2}{*}{ Total } & \multirow{2}{*}{ p Value } \\
\hline & Normal & Hyperlordosis & & \\
\hline Normal 3 & $1(83,8 \%)$ & $6(16,2 \%)$ & $37(100 \%)$ & $0,000^{*}$ \\
\hline Overweight & $16(59,3 \%)$ & $11(40,7 \%)$ & $27(100 \%)$ & \\
\hline Obesse & $4(16,7 \%)$ & $20(83,3 \%)$ & $24(100 \%)$ & \\
\hline
\end{tabular}

Based on the table above, the P value of high Body Mass Index (BMI) and hyperlordosis is 0.000 , with the significance value is $<0.005$. This means there is significance relationship between high Body Mass Index (BMI) with hyperlordosis in students.

Table 4. The Relationship between Waist Circumference with Hyperlordosis

\begin{tabular}{|c|c|c|c|c|}
\hline \multirow[b]{2}{*}{ Circumference } & \multicolumn{2}{|c|}{ Lumbal Curve } & \multirow{2}{*}{ Total } & \multirow{2}{*}{ p Value } \\
\hline & Normal & Hyperlordosis & & \\
\hline \multirow[t]{2}{*}{ Normal } & $44(74,6 \%)$ & $15(25,4 \%)$ & $59(100 \%)$ & \\
\hline & & & & $0,000^{*}$ \\
\hline Excess & $7(24,1 \%)$ & $22(75,9 \%)$ & $29(100 \%)$ & \\
\hline
\end{tabular}

${ }^{*} \mathrm{p}<0,05=$ Significance $($ Chi-Square $)$ 
Based on the table above, the $\mathrm{P}$ value of waist circumference and hyperlordosis is 0.000 , with the significance value is $<0.005$. This means there is significance relationship between excess waist circumfrence with hyperlordosis in students.

\section{DISCUSSION}

Lumbar lordosis is a shifted of lumbar curvature toward the anterior body. In normal standing position, the lumbar curvature will be in the midline when viewed from the lateral side of the body. But in the hyperlordosis, the midline of lumbar curvature will be more posterior of the body (figure 1). ${ }^{10}$

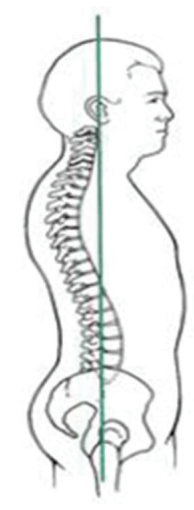

A Ideal

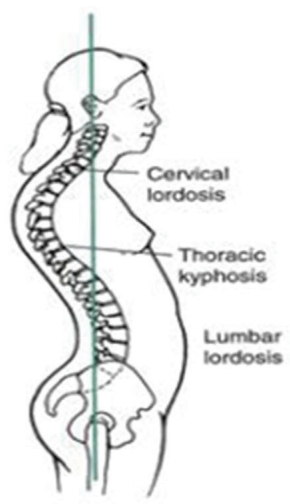

B Exaggerated
Figure 1. Normal Position and Hyperlordosis

Position

The focus of this study was the relation between body mass index and excess waist circumference associated with an increase of the lumbar curve (hyperlordosis). The high body mass index was measured by measuring body weight and height, while to measure the waist circumference was using the tape measure. ${ }^{11,14}$ The lumbar curve is measured using a flexible ruler.
Waist circumference with the increased lumbar curve in this study found a siginificance relationship. Some research also showed the relation of waist circumference and increased of lumbar curve. In high BMI, there was aweakness of the abdominal muscle that will change the gravitational line and the center of gravity forward, so that the curve of lumbal will compensate to shifting forward from the body midline. ${ }^{12,16,19}$

Based on the body mass index, the respondents in this study showed the significant result with the increased of lumbar curve (hyperlordosis), where the P Value was 0.000 . With an increase lumbar curve, vertebral bone biomechanism will be changed through increased body load on facet joints and increased strength shifting from the lumbosacral junction, resulting in misalignment. Increased lumbar curve in individual obesity occurs because of compensation to improve balance.

\section{CONCLUSION}

Based on this study, that was obtained in young adult, there were a correlation between higher BMI and excess waist circumference with the increased of curvature in hyperlordosis.

\section{ACKNOWLEDGEMENT}

Researcher wants to thank to dr. Sakinah Umar, Sp.THT and dr.Dyah Ayu Woro S, M.Biomed as the thesis examiner from Faculty of Medicine 
of Trisakti University. As a parent, Researcher wants to thank to Ir. Anugrah Rachmanto, MT and Mariani Karmidi for the support and the motivation. Researcher also would like to thank Fitriana Rahmayanti as a co-researchers, also for students and staff of Civil Engineering at Department of University of Indonesia who has allowed researchers to do research, for Rajab Ali Mehraban as a closest person to support and provide motivation, and for the students also staff of Trisakti University who has help researchers in terms of which related to thesis.

\section{REFFERENCES}

1. Riset Kesehatan Dasar 2013. Available at:http://www.depkes.go.id/resources/ download/general/Hasil\%20Riskesdas $\% 2$ 02013.pdf. Accessed on May 07,2017.

2. Salam A. Faktor risiko kejadian obesitas pada remaja. J MKMI. 2010;6(3):185-190.

3 Parjoto S. Pentingnya memahami sikap tubuh dalam kehidupan. Jakarta; IFI Graha Jati Asih. 2007;7.

4. Koesyanto H. Masa kerja dan sikap duduk terhadap nyeri punngung bawah. J Kesehatan masyarakat. 2013;1:9-14.

5. Taweetanalarp S, Purepong N. Comparison of lumbar spinal angle between normal body massa index and overweight young adults. J. Phys. Ther. Sci. 2015;27:2343-6.

6. Been L, Kalichman L. Lordosis Lumbar. J the spine. 2014;14:87-92.

7. Widodo WS, Wahyuni. Korelasi antara kegemukan dengan peningkatan kurva lumbal bidang sagital. J Kesehatan.
2008;1:155-64.

8. Seidi F, Rajabi R, Ebrachimi TI, Tavanai AR, Moussavi SJ. The Iranian flexible ruler reliability and validity in lumbar lordosis measurement. J sport sciences. 2009;2(2): 95-9.

9. Tizabi A, Mahdavinejad R, Azizi A, Jafarnejadgero T, Sanjari M. Correlation between height, weight, BMI with standing thoracic and lumbar curvature in growth ages. J sport sciences. 2012;7(1):54-6.

10. Wiboworini B. 2007. Gizi dan Kesehatan. Jakarta: Sunda Kelapa. 2007.

11. AHA. Obesity Information. 2011. Available at:http://www.heart.org/HEARTORG/ GettingHealthy/WeightManagement/ Obesity/ObesityInformation_UCM_3 07908_Article.js p, accesed on Desember 1, 2017

12. Badan Penelitian dan Pengembangan Kesehatan. Riset Kesehatan Dasar 2007. Jakarta: Balitbangkes Depkes. 2007.

13. Sugianti, E. Faktor Risiko Obesitas Sentral Pada Orang Dewasa di Sulawesi Utara, Gorontalo dan DKI Jakarta. Skripsi. Bogor: Fakultas Ekologi Manusia Institut Bogor. 2009.

14. Cameron A.J, Timothy W, Paul Z.Z, David W.D, Neville O, Marita D,

15. Damien J, and Jonathan E.S. Overweight and obesity in Australia: The 1999-2000 Australian diabetes, obesity and life style study. Med J Aust. 178(9):427-423. 2003.

16. Rajabi R, Seidi F, Mohamaadi F. Which method is accurate when using the flexible ruler to measure the lumbar curvature 
angle? Deep point or mid point of arch; World Applied Sciences. 2008;4(6):849-52.

17. Waist Size Matters. Available at: https://www.hsph.harvard.edu/obesitypreventionsource/obesitydefinition/ abdominalobesity/ Accessed on Desember 1,2017

18. Assessing Your Weight and Health Risk. Available at: http://www.nhlbi.nih.gov/ health/edu cational/lose_wt/risk.htm accesed on Desember 1, 2017

19. Abdominal obesity and your health. Available at: http://www.health.harvard. edu/familyhealthguide/abdominal-obesityandyour-health Accessed on Desember 1, 2017

20. Zhang C, Rexrode KM, van Dam RM, Li TY, Hu FB. Abdominal obesity and the risk of allcause, cardiovascular, and cancer mortality: sixteen years of follow-up in US women. Circulation. 2008;117:1658-67.

21. WHO. Global Prevalence Of Diabetes And Obesities. Geneva. 2007. Available at:http:// ebrary.ifpri.org/utils/getfile/collection/ p15738coll2/id/129815/filename/130026. pdf. Accessed on May 05,2017.

22. Kementrian Kesehatan 2013. Available at: http://www.depkes.go.id/resources/ download/general/Hasil\%20Riskesdas\%20 2013.pdf. Accessed on May 01,2017.

23. Waspadji S, Suyono S, Sukardji K, Hartati B. Pengkajian status gizi studi epidemiologi. Jakarta: FKUI. 2003.

24. Novitasary MD, Mayalu N, Kowengian S. Hubungan antara aktivitas fisik dengan obesitas pada wanita subur peserta
JAMKESMAS di Puskesmas Wawonasa Kecamatan Singkil Manado. J e-Biomedik. 2013;1(2):10406.

25. Mukherjee B, Hossain CM, Mondal L, Paul P, Ghosh MK. Obesity and insulin resistance: an abridged molecular correlation. Lipid Insights. 2013;6:1-Availableat:http:// www.ncbi.nlm.nih.gov/pubmed/25278764. Accessed on May 06,2017.

26. Gbary AR, Kpozehouen A, Houehanou YC, Djrolo F, Amoussou MPG, Tchabi Y, et al. Prevalence and risk factors of overweight and obesity: findings from a cross-sectional community-based survey in Benin. Global Epidemic Obesity. 2014;2:3. Available at: http://www.hoajonline.com/journals/pdf/20 52-5966-2-3.pdf. Accessed Mei 07,2017.

27. Mistry sk, Puthussery s. Risk factors of overweight and obesity in childhood and adolescence in south Asian countries: a systematic review of the evidence. J public health. 2015.

28. Rajabi R, Seidi F, Mohamaadi F. Which method is accurate when using the flexible ruler to measure the lumbar curvature angle? Deep point or mid point of arch; World Applied Sciences. 2008;4(6):849-52.

29. Onis MD, Garza C, Onyango AW, Brorghi E. Comparison of the who child growth standarts and the cdc 2000 growth chart. J nutr. 2007;137:144-8.

30. Kisner C, Colby LA. Therapeutic Exercise5th edition. Philadepia : F.A. Davis Company. 2007;5:394-5.

31. WHO. Waist circumference and waisthip ratio; Geneva. 2008. 
Available at:http://apps.who.int/iris/ bitstream/10665/44583/1/9789241501491 eng.pdf. Accessed on May 07, 2017.

32. McAnany SJ, Patterson DC, Overley S, Alicea D, Qureshi SA. The Effect of Obesity on the Improvementin Health State Out comes following Minimally Invasive Transforaminal InterbodyFusion. J Global Spine. 2016;6:744-8.

33. Harkani, Ilyas M, Liyadi F, Idris N, Muis A,Seweng A. Correlation on lumbosacral angle on the degree nerve root suppesion on HNP patients based on MRI examination. Makassar: FK Hassanudin. 2012.
34. Assessing Your Weight and Health Risk. Available at: http://www.nhlbi.nih.gov/ health/educational/lose_wt/risk.htm accesed on Desember 1, 2017

35. Abdominal obesity and your health. Available at: http://www.health.harvard. edu/familyhealthguide/abdominal-obesityandyour-health Accessed on Desember 1, 2017

36. Zhang C, Rexrode KM, van Dam RM, Li TY, Hu FB. Abdominal obesity and the risk of allcause, cardiovascular, and cancer mortality: sixteen years of follow-up in US women. Circulation. 2008;117:1658-67. 